\title{
Tyskland: De nedskruede forventningers tid
}

\section{Peter Wivel}

\section{Angela Merkel har ingen realistiske forslag til at bringe de forgældede eurostater - herunder Tysk- land selv - flot efter krisen. Men hun har holdt sammen på det europæiske projekt, i samarbejde med SPD og De Grønne}

Det sker så sjældent, at det må ligge tæt på aldrig, at en tysk satirisk tegning fortjener omtale for det gode. Men en måned før valget bragte Tysklands største seriøse avis Süddeutsche Zeitung en tegning på sin opinionsside, der ramte situationen nogenlunde rent: En letpåklædt kvinde fortæller med et skilt publikum, at boksekampen nu går ind $\mathrm{i}$ sin 8. omgang. I det ene ringhjørne sidder en mørbanket Peer Steinbrück og sunder sig med et håndklæde om nakken. Midt i ringen hænger en megastor sandsæk som dem, boksere bruger til træning. $\mathrm{Og}$ i det modsatte hjørne sidder ingen.

Siden den 66-årige Steinbrück blev bragt i spil som Socialdemokratiet, SPD's kanslerkandidat i september i fjor, har valgkampen været benhård og op ad bakke. Steinbrück har været sendt til tælling mange gange, især efter hårde stød under bæltestedet og i ryggen. Angela Merkel har han knap nok haft tid til at føle på tænderne, for SPD har haft travlt med en intern valgkamp, der vil gå over i historien, og som har slugt alle partiets kræfter. I offentligheden har den siden september $\mathrm{i}$ fjor mest drejet sig om spørgsmålet: Hvordan får SPD fjernet spidskandidaten Steinbrück langt nok fra hans egne velkendte udiplomatiske, præcise og altid befriende uromantiske synspunkter.

Partiledelsen under anførsel af Sigmar Gabriel, SPD's formand, har med sin kampagne neutraliseret den tiltrækningskraft, Steinbrück kunne have haft på svingvælgere $\mathrm{i}$ midten af tysk politik. Vælgerne er i stedet blevet præsenteret for den 
uoprigtige socialdemokratiske kanslerkandidat, der har andres meninger, men ikke sine egne. Han ligner en slagen mand, der tilsyneladende har glemt alt om den ofte vittige kritik, han i bedste mening gav sine partifæller i erindringsbogen Unterm Strich, der med et par gode danske ord betyder noget i retning af facit eller summa summarum.

I sin velskrevne bog, der fortrinsvis handler om Steinbrücks tid som socialdemokratisk finansminister i Merkels første regering fra 2005 til 2009, en borgerlig-socialdemokratisk koalitionsregering, beskriver han i sidste halvdel sit eget parti som alt for topstyret, alt for svagt og eftersnakkende på det regionale og lokale niveau og først og fremmest et parti uden dagsordensættende fremtidsvisioner. SPD bliver alt for ofte, efter Steinbrücks mening med urette, anset for et parti for tabere og folk, der er blevet overhalet af udviklingen.

\section{Det oplyste borgerskab}

Selvfølgelig skal man samle taberne op og skabe et retfærdigt samfund, og få socialdemokratiske toppolitikere har givet bedre og mere radikale opskrifter på det end Steinbrück. Vælgerne vil ikke identificere sig med tabere, heller ikke socialdemokratiske vælgere. De vil ikke ses som dem, der trak det korteste strå i samfundets vildt accelererende modernisering og globalisering. De vil se en fremtid for sig selv og deres børn i SPD's valgprogram. Det gør de ikke i dag, frygter Steinbrück.

Efter Steinbrücks mening skal man ikke gå på stemmefiskeri hos det postkommunistiske Venstreparti. SPD skal, mener Steinbrück, appellere til fagligt kvalificerede industriarbejdere og højtuddannede, der tjener deres penge i innovative virksomheder. Han tænker ikke mindst på kvinder, der kun langsomt får adgang til arbejdsmarkedet, skønt deres akademiske resultater statistisk set ligger over mændenes. Det oplyste borgerskab, kalder han sin målgruppe.

"SPD var i efterkrigstiden altid i stand til at skaffe flertal, når det på én og samme tid kunne præsentere tre profiler: høj social kompetence, økonomisk sagkundskab og ambitionen om at være platform for de kreative, ukonventionelle, politisk interesserede, men frie ånder i republikken - de 'offentligt engagerede intellektuelle' fra kunst, kultur, videnskab, medier og foreninger", skriver Steinbrück: "Hos dem drejer det sig alle sammen om multiplikatorer, der aldrig må forekomme politisk instrumentaliseret, men som kunne vindes for et forum, hvor landets og samfundets fremtidsproblemer kunne diskuteres kontroversielt og med nye idéer uden for den slagne vej”.

Peer Steinbrück var i september i fjor SPD's eneste oplagte kanslerkandidat og den eneste, der ville 
have en mulighed for at give Merkel modstand. Han har kolossal politisk erfaring, af type som en nordisk socialdemokrat. Han har været erhvervsminister i Slesvig-Holsten og Nordrhein-Westfalen, hvor han endte som ministerpræsident fra 2002 til 2005.

\section{Straf til Schröder}

Steinbrück tabte i maj 2005 denne socialdemokratiske højborg til CDU, Merkels parti - ikke på grund af sin egen indsats, men fordi skuffede SPD-vælgere ville straffe den daværende socialdemokratiske kansler Gerhard Schröder for hans store arbejdsmarkedsreform, Agenda 2010.

I den efterfølgende borgerlig-socialdemokratiske koalitionsregering fik Steinbrück jobbet som finansminister. På denne nøglepost hentede han tysk økonomi tilbage fra afgrunden og befæstede den så sikkert, at Tyskland kunne overleve det globale chok efter Lehman Brothers konkurs i september 2008 og det efterfølgende økonomiske sammenbrud. Uden Steinbrücks indsats havde Merkel næppe triumferet ved valget i 2009.

To andre mulige navne var partiets gruppeformand i Forbundsdagen, den bundsolide Frank-Walter Steinmeier, og Sigmar Gabriel. Men partiet gjorde forsøget med Steinmeier i 2009, og han tabte fatalt til Merkel. Gabriel er en lunefuld, men ekstremt dygtig politiker. Han ud- nytter den mindste blottelse hos modstanderen til at få et rent stød igennem. Han er solid og sympatisk, men vælgerne ser ham mest som en taktiker. God at kvæle en øl med, ikke rar at have til fjende og uegnet til at lede Tyskland.

I årene efter 2009, hvor Steinbrück for første gang blev indvalgt i Forbundsdagen, brugte han også tiden på at holde højtbetalte foredrag for eksklusive forsamlinger.

Efter at hans kanslerkandidatur blev officielt i september 2012 brugte regeringen hans foredragshonorarer i en kampagne, der skulle sværte ham til som en dårlig socialdemokrat. Der kom andre forhold til, en uheldig valgt medierådgiver, en bemærkning om billig rødvin og meget andet, der holdt forargelsesmaskineriet kørende, uden at det havde det ringeste at gøre med det afgørende valg, Tyskland stod overfor.

Mange kommentatorer vred sig i hænderne og beklagede hetzen med henvisning til den afgrund, der åbner sig mellem kanslerens altid ubestemmelige, forsigtige og afmålte politikerfloskler og den rene vare, der flød ud af Steinbrücks mund.

\section{SPD's politiske selvmord}

Hans fjender, og de var mange, især i hans eget parti, tilgav ham tilsyneladende aldrig, at han var en personlighed, og ikke en snusfornuftig professionel politiker som fx Hanne- 
lore Kraft, den socialdemokratiske ministerpræsident i det tilbageerobrede Nordrhein-Westfalen. Kraft tager aldrig en vision i sin mund, men taler til sine vælgere som den hjemmegående husmor, hun ikke er.

SPD's politiske selvmord synes at have været en succes. Meningsmålingerne i august viste partiet på en langsom, men sikker vej ned imod resultatet fra valget til Forbundsdagen i 2009, altså det forrige valg, hvor Steinmeier var partiets kanslerkandidat. Her fik SPD 23 procent af stemmerne.

Det var partiets dårligste resultat siden Forbundsrepublikkens grundlæggelse i 1949. I de sløje år efter krigen lå partiet ved to valg under 30 procent af stemmerne, men dog med procenttal, som ingen socialdemokrat i dag tør drømme om.

Siden har SPD altid hentet mere end 30 procent af stemmerne hjem, i Brandt-årene over 40 procent, ved valget i 200534,2 procent - og alligevel tabte partiet for otte år siden magten til Merkel. De Grønne, SPD's regeringspartner fra 1998 til 2005 blev dengang straffet af sine egne vælgere og fik kun 8,1 procent af stemmerne. Det rakte ikke til en ny rød-grøn regering.

Steinbrück står for en konsekvent politik over for Europas banker og skattely. Finanskapitalismen skal tæmmes, det har også været hans konsekvente kurs i årene i opposition. Han er for en mere retfærdig skatteprogression, for et mere soci- alt retfærdigt skolesystem. Men hvert eneste af hans initiativer er blevet mere diskuteret og kritiseret i SPD end af regeringen.

\section{Tvivlsom regeringspartner}

Men aldrig har chancerne for en tysk kursændring været så store $\mathrm{og}$ nødvendigheden så påtrængende. Merkels regering, bestående af hendes eget store borgerlig-kristelige parti, CDU, af CDU's bayerske søsterparti CSU og af det liberale FDP, har været den dårligste og mest ineffektive regering i Forbundsrepublikkens historie. Indenrigspolitisk er intet lykkedes for den, og det, der alligevel er, skyldes tilfældet eller er sket imod kanslerens udtalte eller uudtalte vilje.

I løbet af de fire år, hvor unionspartierne CDU og det bayerske CSU har regeret sammen med det liberale FDP, har den ene katastrofe afløst den anden. Det liberale FDP fik ved valget i 2009 14,6 procent af stemmerne. En så stor tilslutning havde partiet aldrig oplevet i sin historie. Af de 17 forbundsdagsvalg, der har været siden 1949, var det bare 5 . gang, at partiet kom over 10 procent af stemmerne. Hidtidig rekord var 12,8 procent helt tilbage i 1961.

Og partiet har en tanke. Forud for det dramatiske valg til Forbundsdagen i 2002 kundgjorde FDP's næstformand Jürgen Möllemann, at FDP sigtede på at få 18 procent af stemmerne, 'strategi 18', kaldte FDP det. 
Det fik 7,4, og Möllemann tog sit eget liv under et faldskræmsudspring året efter.

Det var blevet afsløret, at han havde ført en delvis anti-israelsk valgkamp med ulovligt indsamlede kampagnemidler, hvoraf 838.000 euro i første omgang stammede fra hans egen virksomhed. Det var imidlertid nærliggende at tro, at det store beløb også kunne have noget at gøre med Möllemanns virke som mangeårig formand for det Tysk-Arabiske Selskab.

Dertil kom, at det magiske tal ' 18 ' ikke er særligt velkomment i Tyskland. I nazikredse står det for bogstaverne A og H. I hans eget parti spekulerede man over, om ikke 18 var valgt $\mathrm{i}$ bevidstheden om 'en dybere betydning'.

Fra dette nulpunkt arbejdede partiet sig op til 9,8 procent af stemmerne ved valget i 2005 , hvor mange liberale tyskere havde fået nok af syv års socialdemokratisk-grøn ledelse i Tyskland. Imidlertid måtte FDP opleve endnu en valgperiode fra de oppositionsbænke, partiet havde måttet tage til takke med efter regeringsskiftet i 1998, da CDU-eneherskeren Helmut Kohl og hans koalitionsregering takkede af.

I 2009 havde FDP således under ledelse af Guido Westerwelle tilbragt 11 år med totalopposition til diverse regeringer.

Disse vaner kunne Westerwelle, der aldrig havde bevist sin egen regeringsduelighed, ikke lægge sig af, selv om han af regeringschefen Angela Merkel fik den fornemme post som vicekansler og udenrigsminister.

\section{Stemmer til låns}

Det rekordhøje resultat 14,6 procent af stemmerne kunne Westerwelle først og fremmest takke de mange tyskere for, der ikke begreb, at den borgerlig-socialdemokratiske regering i foråret 2009 spændte et økonomisk sikkerhedsnet ud under bilfabrikken Opel, der var i en eksistenskrise på grund af manglende efterspørgsel på virksomhedens produkter. Stemmerne var til låns.

Men Westerwelle var uforsigtig. Han fik øjeblikkelig gennemtrumfet en skattemæssig begunstigelse af hotelbranchen, herunder, viste det sig af en af partiets største økonomiske bidragsydere, samtidig med, at han beskyldte det mildt sagt ikke rundhåndede tyske socialsystem for 'senromersk dekadence'.

FDP stod, i året efter det globale $\varnothing$ konomiske krak, for 'skattelettelser', der kun kaldte på hovedrysten, og havde, skæbnesvangert nok, et brud med Tysklands hidtidige atomkraftpolitik på dagsordenen. I de personlige meningsmålinger sank vicekansleren ned på popularitetbarometrets bundplads.

Skattelettelserne blev ikke til noget, men regeringen omgjorde $\mathrm{i}$ 2010 det forlig, som kansler Gerhard Schröders socialdemokratisk- 
grønne koalitionsregering havde indgået ti år tidligere med den tyske atomkraftindustri. Forliget var ophævet til lov i 2002. Selv om industrien var blevet rigeligt kompenseret for kravet om, at det sidste atomkraftværk skulle slukke i 2022, påvirkede den massivt den ny borgerlig-liberale regering med det resultat, at de for længst nedskrevne atomkraftværker kunne få lov at fortsætte ud over 2022, nogle helt frem til midten af århundredet.

\section{Exit Jung}

I mellemtiden havde Merkel måttet sige farvel til sin første minister efter kun 33 dage på posten. Franz Josef Jung var efter valgsejren blevet flyttet fra forsvarsministeriet til arbejdsministeriet, men blev tvunget til at gå, fordi han umiddelbart før valget havde afgivet urigtige forklaringer om en frygtelig bombetragedie i Afghanistan, som tyske officerer var skyld $i$.

Hans afløser, den politiske komet og baron Theodor zu und von Guttenberg fra det bayerske CSU, holdt helt frem til 1. marts 2011. Sværme af akademikere havde da påvist, at Guttenberg, der pralede offentligt med, at han læste Platons 'Staten' på oldgræesk ved badestranden, havde skrevet mere end halvdelen af sin disputats af.

Samme skæbne led en af Merkels nærmeste fortrolige i regeringen, den profilerede atomkrafttilhænger og undervisningsminister Annette Schavan, i februar i år. Hun havde skrevet nær ved en tredjedel af sin disputats af. Det går ikke, når man har det øverste ansvar for dannelsesniveauet i Tyskland og jæunligt optræder på universiteternes talerstole. Merkel fyrede i 2012 sin energiminister Norbert Röttgen. I et smalt kabinet med kun 17 ministre, kansleren inklusive, betyder fire ministres afgang noget.

Guttenbergs afgang indledte et annus horribilis for Merkels 2. kabinet. Kort efter at det japanske atomkraftværk i Fukushima var forulykket, aflyste regeringen i marts 2011 sin netop vedtagne forlængelse af de tyske atomkraftværkers løbetid. Beslutningen var så upopulær, at kansleren vidste, at hun ville tabe valget i 2013, hvis hun ikke rykkede tilbage til start.

At atomindustrien havde satset næsten alt på forlængelsen, viste det efterfølgende forløb. Direktioner blev udskiftet, aktiekurser styrtdykkede og det svenske Vattenfall meddelte her i sommer, at det trækker sig helt ud af Tyskland.

Ved en stribe delstatsvalg i Hamburg, Sachsen-Anhalt, RheinlandPfalz, Baden-Württemberg, Bremen, Mecklenburg-Vorpommeren og Berlin noterede Merkels parti CDU med en enkelt undtagelse, nemlig Rheinland-Pfalz, stor tilbagegang. CDU mistede magten i Hamburg, og mere katastrofalt i Baden-Württemberg, hvor den skandaleombru- 
ste ministerpræsident Stefan Mappus tabte stort, og partiet De Grønne for første gang nogensinde som det største parti fik en ministerpræsident, den stadig populære Winfried Kretschmann.

Den unge, nykonservative Mappus var en af dem, der blev fanget på det forkerte ben, da bremserne blev slået i for kernekraften i Tyskland. Han købte i december 2010, efter at det var vedtaget at forlænge atomkraftværkernes levetid, i dyre domme og gennem en privat venskabelig bankforbindelse alle aktierne i atomenergikoncernen EnBW, som delstaten var hovedejer af, tilbage fra Frankrig.

Ved valget stod Mappus med et ødelagt ry og et gabende hul i statskassen, og nu må han forsvare sig mod velbegrundede korruptionsanklager ved en retssag, der ikke bliver mindre ydmygende af, at Mappus, mens tid var, fik slettet en mængde bilag i sagen fra sin computer.

\section{Westerwelles afgang}

FDP røg ud af landdagene i Berlin, Bremen og Mecklenburg-Vorpommeren og gik stort tilbage alle andre steder end i Hamburg, hvor FDP som det eneste parti med succes havde modsat sig, at delstatens skoleelever skulle gå sammen i seks år, mod hidtil fire. Denne sejr for det ekstremt socialt uretfærdige tyske skolesystem blev belønnet. Ansvaret for partiets fiasko og kronisk alarme- rende galluptal blev placeret på Guido Westerwelles skuldre, og i maj 2011 gik han af som partiformand.

Som udenrigsminister fulgte Westerwelle efter så store personligheder som Hans-Dietrich Genscher (også fra FDP), Joschka Fischer (De Grønne) og Frank-Walter Steinmeier (SPD). Westerwelle rejser flittigt rundt i verden og taler fredens sag, men til mere end diplomatiske floskler bliver det sjældent.

Westerwelle har, i modsætning til sine seneste forgængere, aldrig fremlagt en strategi for sit virke og Tysklands stilling i verden som EU's største og vigtigste land og verdens fjerdestørste økonomi. Resultatet er, at kansleren har overtaget butikken, og at Westerwelles tid som politiker udløber med septembervalget.

Det hører med til billedet, at kansleren ikke blot kæmper med en regeringspartner, FDP, der de seneste tre år har balanceret på eller ligget nedenunder den høje tyske spærregrænse på 5 procent - og som derfor har måttet markere sig næsten kompromisløst i alle vigtige sager. Merkel skal også tage hensyn til CSU, der ved det seneste delstatsvalg i Bayern i 2008 gik tilbage med 17,3 procentpoint og for første gang siden 1970 fik under 50 procent af stemmerne, nemlig ydmygende 43,4 procent.

Den nyindsatte partiformand Horst Seehofer har siden desperat kæmpet for at genvinde det tabte, og det er sket gennem en populis- 
me, der savner sin mage andre steder i Tyskland. Süddeutsche Zeitung, der udgives i München, opsummerede $i$ august situationen således (citeret efter hukommelsen): "Der findes dårlige argumenter, der findes falske argumenter, og der findes Horst Seehofers argumenter. De sidste unddrager sig al beskrivelse. Det er takket være den fromme katolik Seehofer (der endte med at foretrække sin hustru efter at have fået et barn med sin sekretær), at hjemmegående husmødre fra august $i$ år kan få penge for at passe deres børn hjemme".

Alle andre partier, herunder kanslerens eget, var imod reformen, der spænder ben for tyske kvinders i forvejen stenede vej ind på arbejdsmarkedet, men Merkel måtte bøje sig. Hun vidste, at hvis hun skulle skaffe flertal, ville det ikke ske uden et stærkt CSU i Bayern.

I budgettet for 2014 er afsat en halv milliard euro til projektet. Der bliver penge til overs. Da kasserne åbnede 1. august, måtte familieministerierne i de 16 tyske delstater konstatere, at kun ganske få benyttede sig af tilbuddet. I millionbyen Berlin med mange socialt hårdt ramte familier og en stor indvandrerandel havde kun 31 meldt sig.

\section{Reformer, der ikke blev til noget}

Blandt den lange række af planlagte og påtrængende lovgivningsinitiativer, som den borgerlig-liberale rege- ring ikke har kunnet blive enige om, kan nævnes følgende:

1. Man har endnu ikke, snart 60 år efter kernekraftens debut i Tyskland, fundet en lagerplads, hvor det radioaktive affald kan forblive i årtusinder. Ingen delstat vil sidde tilbage med sorteper.

2. Man har stadig ikke kunnet placere landets finanstilsyn under Forbundsbanken. Det smitter af på Tysklands holdning til et fælles banktilsyn på EU-niveau.

3. Selv om opgivelsen af atomkraft i Tyskland i 2011 skulle være ledsaget af en plan for den såkaldte 'energiomvæltning' med hovedvægt på vedvarende energi og stærk udbygning af energitransportnettet, er intet sket.

4. En stort anlagt sygesikringsreform er ikke blevet til noget. Det tyske sygesikringssystem hviler på bidrag fra arbejdsgiverne og hæmmer derved bevægeligheden på arbejdsmarkedet. En annonceret reform af ældreplejen ligger også brak. Det samme gælder planerne om at gøre pensioneringen af lavtlønnede behovsafhængig og skattebetalt.

5 . Det ifølge OECD stærkt asociale tyske skolesystem trænger til en grundlæggende reform for at komme op på nordisk niveau, men ingen tør tage emnet op - heller ikke SPD. Studentereksaminer er forskellige i de forskellige delstater, og universitetsgraderne kan ikke umiddelbart sammenlignes. Nogle delstater har studiegebyrer, andre ikke. 
6. Selv om den indenlandske efterretningstjeneste, der findes i sin egen version i hver enkelt delstat, og politiet svigtede til fuldkommenhed, mens en nynazistisk gruppe, NSU, myrdede ti mennesker, har regeringen foreløbig ingen forslag til, hvordan det kan blive bedre.

7. Det lykkedes ikke i denne regeringsperiode at enes om regler for langtidslagring af data til brug for bl.a. opklaringsarbejde og terrorbekæmpelse. Opgaven må efter afsløringerne af det amerikanske Prismprogram forekomme uoverstigelige.

8. Regeringen kunne ikke enes om indførelse af mindsteløn, af kvindekvoter i virksomhedernes totalt mandsdominerede bestyrelser og af homoseksuelle vielser.

9. En færdigaftalt dobbeltbeskatningsaftale med Schweiz var så hullet, at den ikke slap gennem Forbundsrådet, det tyske 'overhus', hvor delstaterne er repræsenteret.

\section{Reformkøen}

Reformkøen minder tyskerne om årene under kansler Kohl i 1990'erne, hvor alt efterhånden fik lov at gå i stå. Eneste virkelig reform står blålyset Theodor zu Guttenberg for.

I sommeren 2010 overraskede forsvarsministeren regeringens spareudvalg med et forslag om at afskaffe værnepligten i Tyskland i fredstid. Efter at den første forbløffelse havde lagt sig, blev besparelserne det afgørende argument, og siden som- meren 2011 har Tyskland haft en professionel hær. Det er stadig umådeligt svært at skaffe mandskab, men det gør ingen skår i glæden.

Da Tyskland i 1956 fik lov at genopruste og indtræde i Nato, bestod det tyske forsvare af "borgere i uniform"'. Tyskland havde taget ved lære af Hitler-årene og den prøjsiske militarisme og indrømmede endog sine soldater retten til at nægte at adlyde ordrer. En professionel hær i Tyskland kan derfor ikke ubetinget betegnes som et fremskridt.

\section{Merkel, Merkel, Merkel}

De valgplakater, som CDU har hængt op på gigantiske billbords landet over, viser et eneste regeringsmedlem, nemlig kansleren selv. Det er ikke tilfældigt. Kun Merkel huskes af vælgerne for det gode. Hendes regering er lammet af indre strid, inkompetence eller regelrette skandaler. Eneste undtagelse er den ubestikkelige finansminister Wolfgang Schäuble.

Eurokrisen brød ud i 2009, samtidig med at Merkel dannede sit 2. kabinet, og den vil mere end noget andet være hovedoverskriften på hendes regeringstid. Merkel har, med Schäuble ved sin side, stået for gennemførelsen af alle nationale hjælpepakker og overstatslige redningsfonde.

Under hende er finansstabiliseringsfonden EFSF og den europæiske valutafond ESM gennemført. 
Hun har i nåde set til, at den Europæiske Centralbank på kanten af sit mandat garanterede euroens fortsatte eksistens, hun har overlevet foreløbig to behandlinger af sin egen kriselovgivning ved den tyske Forfatningsdomstol.

Hun har stadig - i modsætning til SPD og De Grønne - ingen realistiske forslag til, hvordan man effektivt kan bringe de forgældede eurostater - herunder Tyskland selv - flot efter krisen.

Men hun har holdt sammen på det europæiske projekt, og det har hun gjort i konstant samarbejde med SPD og De Grønne, men under muggen og modstand fra sine egne. Hendes såkaldte 'sparekurs' over for gældstyngede lande er blevet kritiseret, men ikke helt fair. De suveræne nationer beslutter selv, hvordan de vil reformere sig ud af krisen.

De tyske vælgere ser i Merkel den kansler, der varetager deres interesser på europæisk plan og garanterer stabiliteten i landet. Det bringer hende efter alle solemærker at dømme sejren ved valget den 22. september.

Først derefter vil det vise sig, om hun lever op til så nedskruede og beskedne forventninger.

Peter Wivel er korrespondent $i$ Berlin for dagbladet Politiken og tidligere chefredaktør for Information og Berlingske. 